University of South Carolina

Scholar Commons

$10-12-2012$

\title{
Bullshit!: Why the Retroactive Application of Federal Rules of Evidence 413-414 and State Counterparts Violates the Ex Post Facto Clause
}

Colin Miller

University of South Carolina - Columbia, mille933@law.sc.edu

Follow this and additional works at: https://scholarcommons.sc.edu/law_facpub

Part of the Evidence Commons

\section{Recommended Citation}

Colin Miller, Bullshit!: Why the Retroactive Application of Federal Rules of Evidence 413-414 and State Counterparts Violates the Ex Post Facto Clause, 4 Neb. L. Rev. Bull. 3 (2012), http://lawreviewbulletin.unl.edu/?p=1060. 


\section{Bullshit!: Why the Retroactive Application of Federal Rules of Evidence 413-414 and State Counterparts Violates the Ex Post Facto Clause}

\section{Colin Miller*}

In State v. Kibbee, Eddie Kibbee brought an Ex Post Facto Clause challenge to his convictions for first-degree sexual assault and felony child abuse. ${ }^{1}$ Kibbee was convicted for sexual acts committed against a sixteen year-old, ${ }^{2}$ and if his ex post facto claim had been that the legislature raised the age of consent from sixteen to seventeen after his alleged crimes, he would have had a viable claim. He also would have had a viable claim if his conduct was classified as second-degree sexual assault at the time of his alleged crimes or if he was sentenced to fifty years' incarceration, but the maximum punishment for his crimes was only forty years at the time of commission.

Article I, section 9 of the United States Constitution states in relevant part that "[n]o Bill of Attainder or ex post facto Law shall be passed"’3 by Congress while Article I, section 10 places a similar limitation of state legislatures. ${ }^{4}$ In its opinion in Calder v. Bull, the Supreme Court recognized four types of laws that cannot be applied retroactively consistent with these ex post facto clauses:

1st. Every law that makes an action done before the passing of the law, and which was innocent when done, criminal; and punishes such action. 2d. Every law that aggravates a crime, or makes it greater than it was, when committed. 3d. Every law that changes the punishment, and inflicts a greater punishment, than the law annexed to the crime, when committed. 4th. Every law that alters the legal rules of evidence, and receives less, or different, testimony, than the law required at the time of the commission of the offence, in order to convict the offender. ${ }^{5}$

\footnotetext{
*Associate Professor, University of South Carolina School of Law, Blog Editor, EvidenceProf Blog: http://lawprofessors.typepad.com/evidenceprof/. I would like to thank Cassidy Evans for her research assistance.

${ }^{1}$ State v. Kibbee, 815 N.W.2d 872, 879 (Neb. 2012).

${ }^{2}$ See id.

${ }^{3}$ U.S. Const., art. I , $\$ 9$.

${ }^{4}$ U.S. Const., art. I, $\S 10$.

${ }^{5}$ Calder v. Bull, 3 U.S. (3 Dall.) 386, 390 (1798).
} 
The three hypothetical laws referenced above are the first three types of laws recognized in Calder. The law raising the age of consent criminalized conduct (sexual intercourse with a sixteen year-old) that was innocent when done. The law turning behavior that was previously second-degree sexual assault into first-degree sexual assault aggravated an existing crime, and the law allowing for fifty years' incarceration inflicted a greater punishment than the laws in place at the time of the crime.

Kibbee did not, however, raise any of the above objections. Instead, his claim was that the trial court violated the state ex post facto clause by retroactively applying a rule of evidence that was not codified at the time of his alleged misconduct. ${ }^{6}$ That rule, Nebraska Rule of Evidence 414(1) provides that

In a criminal case in which the accused is accused of an offense of sexual assault, evidence of the accused's commission of another offense or offenses of sexual assault is admissible if there is clear and convincing evidence otherwise admissible under the Nebraska Evidence Rules that the accused committed the other offense or offenses. If admissible, such evidence may be considered for its bearing on any matter to which it is relevant. ${ }^{7}$

Nebraska Rule of Evidence 414(1) is thus similar to Federal Rules of Evidence 413 and 414, which allow for the admission of prior acts of sexual assault and child molestation by criminal defendants. ${ }^{8}$ Kibbee claimed that Rule 414(1) was clearly a law that alters the legal rules of evidence, meaning that it was the fourth type of law that cannot be applied retroactively consistent with the ex post facto clause. Like every defendant before him challenging the retroactive application of Federal Rules of Evidence 413 and 414 as well as state counterparts, Kibbee was unsuccessful. ${ }^{9}$ This

\footnotetext{
${ }^{6}$ Kibbee, 815 N.W.2d 872, 883.

${ }^{7}$ Neb.Rev.Stat. $§ 27-414$.

${ }^{8}$ See Fed.R.Evid. 413 \& 414.

${ }^{9}$ See Kibbee, 815 N.W.2d at 86-90 (cataloging cases across the country upholding such rules against Ex Post Facto Clause challenges).
} 
essay argues that every court that has considered the issue is wrong and that these rules should be classified as the fourth type of law that cannot be applied retroactively.

\section{Carmell v. Texas, Rules of Evidence, and the Ex Post Facto Clause}

In Carmell v. Texas, Scott Carmell appealed from his convictions for various sexual crimes that he allegedly committed against his stepdaughter. ${ }^{10}$ The only evidence supporting some of those convictions was the stepdaughter's testimony, and, at the time of Carmell's offenses, Texas had a so-called "outcry or corroboration" requirement. ${ }^{11}$ Under this requirement, a defendant could not be convicted of certain sex crimes unless, inter alia, the victim's testimony was corroborated by other evidence. ${ }^{12}$ Texas amended this "outcry or corroboration" requirement after Carmell's alleged crimes but before his trial. ${ }^{13}$ Under the amended requirement, the stepdaughter's testimony did not have to be corroborated for the jury to convict Carmell, and, after he was indeed convicted, Carmell brought a successfulex post facto clause challenge. ${ }^{14}$ In granting Carmell's challenge, the Supreme Court found that the "outcry or corroboration" requirement fit comfortably in the fourth Calder category because "[a] law reducing the quantum of evidence required to convict an offender is as grossly unfair as, say, retrospectively eliminating an element of the offense, increasing the punishment for an existing offense, or lowering the burden of proof...."15

In reaching this conclusion, however, the Court indicated in a footnote that "[o]rdinary rules of evidence...do not violate the Clause." 16 Instead, "[r]ules of that

\footnotetext{
${ }^{10}$ Carmell v. Texas, 529 U.S. 513 (2000)

${ }^{11} \mathrm{Id}$. at 517.

${ }^{12}$ See id.

${ }^{13}$ See id. at 518.

${ }^{14}$ See id. at 532 .

${ }^{15} \mathrm{Id}$.

${ }^{16} I d$. at 1633 n.22.
} 
nature are ordinarily evenhanded, in the sense that they may benefit either the State or the defendant in a given case." Moreover and "[m]ore crucially, such rules, by simply permitting evidence to be permitted at trial, do not at all subvert the presumption of innocence, because they do not concern whether the admissible evidence is sufficient to overcome the presumption."18

Given this language, it is easy to understand the opinion of the Supreme Court of Nebraska in Kibbee and similar decisions by courts in states across the country. In Kibbee, the court cited to the language of the above Carmell footnote and found that the retroactive application of Nebraska Rule of Evidence 414(1) did not violate the ex post facto clause because it "is an ordinary rule of evidence which relates to admissibility and simply provides that evidence of prior sexual misconduct may be admitted to prove propensity." 19

\section{A Rule Less Ordinary: Rule 414(1)'s Pro-Prosecution Approach}

Contrary to the Court's conclusion, Nebraska Rule of Evidence 414(1), like Federal Rules of Evidence 413 and 414, is not an ordinary rule of evidence. Federal Rule of Evidence 404(b)(1) states that “[e]vidence of a person's character or character trait is not admissible to prove that on a particular occasion the person acted in accordance with the character or trait." 20

Congress, however, was dissatisfied with the low conviction rates in sexual assault and child molestation cases and decided to float new rules of evidence in the

\footnotetext{
${ }^{17} \mathrm{Id}$.

${ }^{18} \mathrm{Id}$.

${ }^{19}$ State v. Kibbee, , 284 Neb. 72, 90 ,815 N.W.2d 872, 888

${ }^{20}$ Fed.R.Evid. 404(b).
} 
Violent Crime Control and Law Enforcement Act of $1994 .^{21}$ These rules would have been contrary to the general propensity character proscription and allowed for the admission of evidence of a defendant's prior crimes, wrongs, or acts to prove, "once, a rapist, always a rapist," "once a child molester, always a child molester," or any other relevant matter. These new rules were sent for public comment to judges, lawyers, law professors, and legal organizations, with the "overwhelming majority" of respondents opposing the new rules. ${ }^{22}$ Given this response, Congress decided to bypass the typical rulemaking process to enact what are now Federal Rules of Evidence 413-415 (with Rule 415 applying in civil cases). ${ }^{23}$ A number of states followed suit in the ensuing years, with Nebraska joining their ranks in $2010 .^{24}$

Thus, Federal Rules of Evidence 413-415 are not ordinary rules of evidence because Congress circumvented the formal rulemaking process to enact them. This feature makes these Rules irregular but not singular. Instead, Congress also bypassed the rulemaking process to enact Federal Rule of Evidence 704(b) in the wake of the assassination attempt on Ronald Reagan. ${ }^{25}$ In response to the public outrage that stemmed from the jury finding John Hinckley not guilty by reason of insanity, Congress pushed through Federal Rule of Evidence 704(b), which states that

In a criminal case, an expert witness must not state an opinion about whether the defendant did or did not have a mental state or condition that constitutes an element of the crime charged or of a defense. Those matters are for the trier of fact alone. ${ }^{26}$

\footnotetext{
${ }^{21}$ Report of the Attorney General on the Admission of Criminal Histories at Trial, 22 MICH. J. L. REFORM 707, 723-27 (1989).

${ }^{22}$ See Federal Rule of Evidence 413 advisory committee's note.

${ }^{23}$ See Aviva Orenstein, Deviance, Due Process, and the False Promise of Federal Rule of Evidence 403, 90 CORNELL L. REV. 1487, 1488 n.1 (2005).

${ }^{24}$ State v. Kibbee, , 284 Neb. 72, 81815 N.W.2d 872, 883.

${ }^{25}$ See Daniel J. Capra, A Recipe for Confusion: Congress and the Federal Rules of Evidence, 55 U. MIAMI L. REV. 691, 691-93 (2001).

${ }^{26}$ Fed.R.Evid. 704(b).
} 
As this language makes clear, while the passage of Rule 704(b) was extraordinary, the operation of the rule is quite ordinary in the sense that it may benefit either the State or the defendant in a given case. The Rule prevents a criminal defendant from calling an expert to testify that his mental disease or defect prevented him from appreciating the wrongfulness of his actions, but it also precludes the prosecution from presenting an expert to conclude that the defendant was sane. The Rule prevents a criminal defendant from calling an expert witness to testify that the defendant lacked the mens rea of the crime charged, but it also precludes the prosecution from presenting an expert to conclude that he possessed the requisite mens rea, which has rendered inadmissible testimony that police officers "routinely offered" prior to adoption of the Rule. $^{27}$

Conversely, Federal Rules of Evidence 413 and 414 solely benefit the State. The Rules permit the prosecution to present evidence of the defendant's prior acts of sexual assault and child molestation for any relevant purpose while vesting no similar right in the defendant's hands. This was a point partially recognized by the dissent in Carmell. The Carmell dissent observed that the logical extreme of the majority's reasoning was that Rule 413, as a rule that solely benefits the prosecution, "would be ex post facto as applied to offenses committed before its enactment." 28 In reaching this conclusion, however, the dissent treated Rule 413 like it was not aberrational and cited Federal Rule

\footnotetext{
${ }^{27}$ Michael Teter, Acts of Emotion: Analyzing Congressional Involvement in the Federal Rules of Evidence, 58 CAth. U. L. Rev. 153, 191 (2008).

${ }^{28}$ Carmell v. Texas, 529 U.S. 513, 563 (2000) (Ginsburg, J., dissenting).
} 
of Evidence 412(b)(1)(B) as another Rule that could only benefit one party: the criminal defendant. $^{29}$

Rule 412(b)(1)(B) is an exception to Federal Rule of Evidence 412(a), the Rape Shield Rule, which generally prevents a defendant from presenting evidence of the alleged victim's other sexual behavior or sexual predisposition in a civil or criminal proceeding involving alleged sexual misconduct. ${ }^{30}$ Rule 412(b)(1)(B) provides an exception in criminal cases for "evidence of specific instances of a victim's sexual behavior with respect to the person accused of the sexual misconduct, if offered by the defendant to prove consent or if offered by the prosecutor...." 31 As the italicized language makes clear, the Carmell dissent was clearly wrong in characterizing Rule 412(b)(1)(B) as a Rule that solely benefits the defendant because the prosecution could use it to present evidence that the defendant and victim used to engage in consensual sexual acts until, say, an act of violence changed the relationship, which is why the sexual act at issue was nonconsensual. Indeed, Rule 412(b)(1)(B) opens the door for the prosecution to present such evidence for any purpose while defendant may only use the Rule to prove consent.

Even if this were not the case, Rule 412(b)(b)(1)(B) is merely an exception to Rule 412(a), which is designed to prevent defendants from presenting sexual propensity character evidence regarding their victims. In this sense, the Rule 412 as a whole is no different from any number of other Federal Rules of Evidence, such as Rules 407-411,

\footnotetext{
${ }^{29}$ See id.

${ }^{30}$ Fed.R.Evid. 412(a).

${ }^{31}$ Fed.R.Evid. 412(b)(1)(B) (emphasis added).
} 
which each deem a certain category of evidence per se inadmissible subject to certain exceptions. $^{32}$

In this regard, Federal Rule of Evidence 412, viewed as a whole, is similar to every other Federal Rule of Evidence, save three or four, in that it could be used to benefit either side in a given case. As noted, three of the aberrations are Federal Rules of Evidence 413-415. The other anomaly is Federal Rule of Evidence 404(a)(2)(C), which allows the prosecution to present evidence of the victim's character for peacefulness when a homicide defendant claims that the victim was the first aggressor. ${ }^{33}$ The rest of Rule 404(a)(2), however, makes clear that, subject to the limitations of Rule 412, a defendant in any type of criminal trial can always present propensity character evidence concerning the victim (as well as himself). ${ }^{34}$

Conversely, under Rules 413 and 414, a prosecutor can present evidence of the defendant's other acts of sexual assault and child molestation while Rule 412 generally precludes a defendant from presenting evidence of his victim's other sexual acts. Thus, Rules 413 and 414 (and 415 in the civil context) are an island unto themselves. They are not ordinary rules of evidence, and they are extraordinary in precisely the way that subjects them to Ex Post Facto scrutiny according to both the majority and dissenting opinions in Carmell. So, why have courts categorically upheld these Rules and state counterparts against ex post facto challenges?

Presumed Innocent: The Presumption of Innocence and the Propensity Character Evidence Proscription

\footnotetext{
${ }^{32}$ See Fed.R.Evid. 407-411.

${ }^{33}$ Fed.R.Evid. 404(a)(2)(C).

${ }^{34}$ See Fed.R.Evid. 404(a)(2)(A)\&(B).
} 
The Carmell majority regarded most rules of evidence as "ordinary" in a second regard in that they do not at all subvert the presumption of innocence. As support for its conclusion in Kibbee, the Supreme Court of Nebraska characterized Nebraska Rule of Evidence $414(1)$ as one of these ordinary rules. ${ }^{35}$ But once again, Federal Rules of Evidence 413-414 and state counterparts are the one anomaly in a constellation of evidentiary rules that otherwise do not subvert the presumption of innocence.

On numerous occasions, courts have noted that Federal Rule of Evidence 404(b), the propensity character evidence proscription, is in place to maintain the presumption of innocence. ${ }^{36}$ If the prosecution were able to present evidence of a defendant's prior robberies to prove, "once a robber, always a robber," evidence of a defendant's prior arsons to prove, "once an arsonist, always an arsonist," or evidence of a defendant's prior rapes to prove, "once a rapist, always a rapist," the presumption of innocence would be eviscerated. As the United States Court of Appeals for the Third Circuit cautioned in Government of the Virgin Islands v. Toto, when evidence of a defendant's prior crimes reaches the jury, "it is most difficult, if not impossible, to assume continued integrity of the presumption of innocence" because "[a] drop of ink cannot be removed from a glass of milk." 37 Therefore, Federal Rules of Evidence 413 and 414 do subvert the presumption of innocence unless Congress is asking courts to assume the impossible.

The point, though, is that Congress clearly did not ask courts to assume the impossible. Instead, subverting the presumption of innocence was the goal of Federal Rules of Evidence 413 and 414 and not merely their result. As noted, Congress proposed Rules 413-414 because it was dissatisfied with the conviction rates in sexual assault and

\footnotetext{
${ }^{35}$ See State v. Kibbee, 815 N.W.2d 872, 888 (Neb. 2012).

${ }^{36}$ See, e.g., United States v. Crowder, 141 F.3d 1202, 1212 (D.C. Cir. 1998).

${ }^{37} 529$ F.2d 278, $283\left(3^{\text {rd }}\right.$ Cir. 1976).
} 
child molestation cases and wanted prosecutors to be able to use the new rules as a tool to increase these rates of conviction. ${ }^{38}$

This is the crux of the argument for why Federal Rules of Evidence 413, 414, and state counterparts should be treated as the fourth type of law that cannot be applied retroactively consistent with the ex post facto clause. These rules are not ordinary rules of evidence that can favor either side, nor are they rules that the prosecution can only use to prove a discrete part of its case. Rather, the rules are a naked attempt by Congress (and now state legislatures) to allow prosecutors to achieve convictions through sexual propensity character evidence when they would otherwise be unable to prove guilt beyond a reasonable doubt.

As noted, both Federal Rule of Evidence 413 and Nebraska Rule of Evidence 414(1) allow a prosecutor to present evidence of a defendant's act of sexual assault "for its bearing on any matter to which it is relevant," and this "any purpose" language appears in Rule 414 as well. ${ }^{39}$ Therefore, under these rules, the jury could use evidence of a defendant's prior sex crime(s) as the sole evidence to find that the defendant satisfied both the actus reus and mens rea of the sexual crime charged. Moreover, such a result would not be surprising given courts' extreme reluctance to use Federal Rule of Evidence 403 and state counterparts to exclude or circumscribe the use of sexual propensity character evidence. ${ }^{40}$ Federal Rules of Evidence 413 and 414 and state counterparts thus squarely qualify as "law[s] that alter[] the legal rules of evidence, and receive[] less, or different, testimony, than the law required at the time of the commission of the offence,

\footnotetext{
${ }^{38}$ See supra note 20 and accompanying text.

${ }^{39}$ See Fed.R.Evid. 413; Neb.R.Evid. 414(b).

${ }^{40}$ See Orenstein, supra note 22, at 1491 (noting that courts, and especially the Eighth Circuit, have rendered Rule 403 toothless and ineffectual in such cases).
} 
in order to convict the offender. As such they cannot be applied retroactively consistent with the ex post facto clause. 